\title{
WATER SECTOR MANAGEMENT AND SUSTAINABLE DEVELOPMENT OF BULGARIAN REGIONS
}

\author{
Nikolay Tsonkov \\ Scientific and Research center of regional studies, University of National \\ and World Economy, Sofia, Bulgaria \\ https://orcid.org/0000-0002-9169-6511
}

CMESTE

JEL Category: Q01, R58

\begin{abstract}
When speaking about facilitating normal conditions for living and working, in the modern world, water resources are significant. We need to maintain water safety according to the specific environment and particular territory demands. Water resources are renewable natural resources, but they are unevenly distributed in the world territory. This fact turns water resources into priceless valued property. In the future, most conflicts will occur because of the limited amount of water resources and their unbalanced distribution in the world. That is why water resources and water sector management become the most dominant activities in the sustainable development of regions. This research is to outline the role of water sector management in the context of sustainable and regional development. The author uses systemic, and territory approaches and systemic, descriptive, analytic, comparison, and other methods for purpose achievement. The specific aim of this research is to point out the problems and challenges of Bulgarian water resources management through an analyze the system of water sector management. The null hypothesis of the author is that there is a strong connection between water resources and water sector management and sustainable development of the regions, concerning regional development. The author fulfills the research aim using systemic and territorial approaches and different scientific methods as descriptive, comparison, analytical, expert opinion citation, and others.
\end{abstract}

Keywords: water resources, water sector, management, sustainable development, regional development, region

\section{INTRODUCTION}

Water scarcity affects more than $40 \%$ of the global population. Water-related disasters account for $70 \%$ of all deaths related to natural disasters. The World Bank helps countries ensure the sustainability of water use, build climate

Address of the author:

Nikolay Tsonkov

䒠”n.tzonkov@unwe.bg resilience, and strengthen integrated management. Today, most countries are placing unprecedented pressure on water resources. The global population is growing fast, and estimates show that with current practices, the world will face a $40 \%$ shortfall between forecast demand and available supply of water by 2030 . Feeding 9 billion people by 2050 will require a $60 \%$ increase in agricultural production, (which consumes $70 \%$ of the resource today), and a $15 \%$ increase in water withdrawals. Besides this increasing 
demand, the resource is already scarce in many parts of the world. Estimates indicate that $40 \%$ of the world population lives in water-scarce areas, and approximately one-quarter of the world's GDP is exposed to this challenge. By 2025, about 1.8 billion people will be living in regions or countries with absolute water scarcity. Water security is a major and often growing challenge for many countries today. (IBRD-IDA, 2017)

Bulgaria is traditionally rich speaking about water resources - land and underground rivers, mineral springs, the infrastructure of dams, and other facilities that are built to meet the needs of the population for water for domestic and industrial needs.

Due to climate change, the state of water resources in Bulgaria is gradually changing. In recent years, there has been a decline in rainfall, which affects the levels of drinking water sources - rivers, dams, and others. That is why the management of water resources, and the related sector is gaining more and more importance.

\section{DISCUSSION}

\subsection{Water resources and water sector in Bulgaria}

The water resources of the state are vital for the normal course of the reproductive, economic, spatial-urban, and other processes. For example, cities and countries arise naturally near a water source. Water is an objective necessity for man and without the availability of resources man cannot exist. In this sense, the main requirement of the human population for the environment is the availability of food and water. One example of a settlement that has grown into a city is in Australia. This continent is not rich in freshwater resources. The settlement arises near a gold mine, which determines the economic profile of the region. But there is an objective problem. There is no water source to meet the vital needs of the habitants. Because of this reason, it was decided to build a water supply system, which is still one of the longest water facilities ever built. Its length is around $400 \mathrm{~km}$.

In Bulgaria, the relative distribution of water resources is balanced. It is formed because of natural land and underground rivers, and the built infrastructure of dams, water intakes, catchments, and other facilities. In recent years, there has been a decline in the total amount of water resources, including the Danube. The use of water resources is an exclusive competence of the state through the built infrastructure, its maintenance, and public institutions for management. The totality of all elements of the infrastructure forms the water sector in Bulgaria.

Water resources change their quantity depending on climatic factors. They depend largely on the annual rainfall, snowmelt, and their use. From 2013 to 2017 we see a decline. In 2013, the total water resource of the Bulgarian state was 114,322 million $\mathrm{m}^{3}$. In 2015 , this resource was 110,775 million $\mathrm{m}^{3}$, and in 2016, 107,217 million $\mathrm{m}^{3}$. At the end of the period under review in 2017, the total resource fresh water and available groundwater available for annual use are 87,488 million $\mathrm{m}^{3}$ (Kolcheva, 2019).

Bulgaria is divided into four regions - Danube, Black Sea, East Aegean, and West Aegean. The water sector in Bulgaria includes - dams, water intake facilities, drinking water treatment plants, water supply network, water supply network facilities, sewerage network, and network facilities, wastewater treatment plants, and hydroameliorative facilities. The Bulgarian state has 53 significant dams with a volume of $6,697.8$ million $\mathrm{m}^{3}$. The smaller dams in Bulgaria are 2,736 with a total volume of 1,436 million $\mathrm{m}^{3}$ (Kolcheva, 2019).

\subsection{Water sector and resources management and regional development}

Each country has many different social systems to meet the needs of the population. The water sector is especially important even for the development of the country. Logically, the normal, efficient, and proper functioning of this system depends on its management. In recent years we have witnessed several cases of improper management of the water sector, which has led to water regimes in some areas of Bulgaria.

The development of the water sector of the Bulgarian state is related to the territorial development of the individual regions. There is a strong connection between the management and development of the Bulgarian water sector, the spatial and regional development of Bulgaria.

The availability of water resources and the management of the water sector in Bulgaria are 
part of the strategies for the sustainable development of the regions. Water is a key resource for the maintenance and normal functioning of human communities in Bulgarian regions. Proper water management and conservation for future generations is an important priority of the state and municipalities. The development of the regions is inconceivable without the availability of water resources. On the other hand, land improvement and spatial development of the territory are also directly dependent on water sources and their use.

Not only the population and the creation of living conditions but also the regional economy and food play a role in the rational and sustainable development of the territory. Agriculture, a large part of industrial and processing enterprises also needs water for their normal operation. That is why another important condition, which is a link between regional development and water resources, is infrastructure. We could say that the water sector of Bulgaria covers tangible and intangible elements. The material component is the infrastructure, and the intangible component is related to water management.

The management of the water sector in Bulgaria concerns the renewal of water in terrestrial sources, maintenance of sufficient quantities of water, consumption of the resource, feeding the population of the respective territory, production, and agriculture. That is why it is important to analyze the process of water resources recovery and consumption. Related to this are the forecasts for the expected quantities of water from different sources, the development of the population and the economy in the regions. As can be seen in Table 1, demographic projections show a population decline, which means a decline in consumption in the long run.

Table 1. Demographic forecasts by regions of water management.

\begin{tabular}{|l|l|c|c|c|c|c|c|c|}
\hline № & 2010 & 2011 & 2012 & 2015 & 2021 & 2027 & 2035 \\
\hline 1. & Total, residents & $7,528,103$ & $7,490,705$ & $7,453,040$ & $7,337,862$ & $7,094,897$ & $6,839,791$ & $6,534,980$ \\
\hline 1.1. & Danube region & $3,306,524$ & $3,289,059$ & $3,271,532$ & $3,218,307$ & $3,107,857$ & $2,995,261$ & $2,871,430$ \\
\hline 1.2. & Black sea region & $1,336,992$ & $1,335,024$ & $1,333,027$ & $1,326,815$ & 1313964 & $1,294,195$ & $1,270,867$ \\
\hline $\begin{array}{l}\text { 1.3. } \\
\text { Eastern Aegean } \\
\text { region }\end{array}$ & $2,268,520$ & $2,254,834$ & $2,241,012$ & $2,198,525$ & $2,107,434$ & $2,013,366$ & $1,892,227$ \\
\hline 1.4. & $\begin{array}{l}\text { West Aegean } \\
\text { region }\end{array}$ & 616,067 & 611,788 & 607,469 & 594,216 & 565,642 & 536,969 & 500,456 \\
\hline
\end{tabular}

Source: National Statistical Institute, Bulgaria

In the following table, we see the ratio between future water consumption and expected quantities following the synonymous forecasts. As is clear from the long-term data, there is a

Table 2. Comparison between future water consumption until 2035 and water quantity in dams in Bulgaria

\begin{tabular}{|c|c|c|c|c|c|c|c|c|}
\hline \multirow[b]{2}{*}{ № } & & \multirow{2}{*}{$\begin{array}{c}\text { Total } \\
\text { water } \\
\text { volume, } \\
\text { Million } \mathrm{m}^{3}\end{array}$} & \multicolumn{2}{|c|}{$\begin{array}{l}\text { Future consumption } \\
\text { In the year } 2015\end{array}$} & \multicolumn{2}{|c|}{$\begin{array}{l}\text { Future consumption } \\
\text { In the year } 2021\end{array}$} & \multicolumn{2}{|c|}{$\begin{array}{l}\text { Future consumption } \\
\text { In the year } 2035\end{array}$} \\
\hline & & & $\begin{array}{l}\text { Quantity, } \\
\text { Million } \mathrm{m}^{3}\end{array}$ & $\begin{array}{c}\text { Percentage } \\
\text { of total } \\
\text { volume, } \%\end{array}$ & $\begin{array}{l}\text { Quantity } \\
\text { Million } \mathrm{m}^{3}\end{array}$ & $\begin{array}{c}\text { Percentage } \\
\text { of total } \\
\text { volume, } \%\end{array}$ & $\begin{array}{l}\text { Quantity } \\
\text { Million } \mathrm{m}^{3}\end{array}$ & $\begin{array}{c}\text { Percentage } \\
\text { of total } \\
\text { volume, \% }\end{array}$ \\
\hline 1. & Total & $8,134.8$ & 2,759 & 34 & 2674 & 32.9 & 2,549 & 31.3 \\
\hline 2. & Danube region & $2,346.38$ & 400 & 17 & 429 & 18.0 & 500 & 21.0 \\
\hline 3. & Black sea region & $1,547.0$ & 699 & 45 & 682 & 44.0 & 717 & 46.0 \\
\hline 4. & $\begin{array}{l}\text { Eastern Aegean } \\
\text { region }\end{array}$ & $3,628.5$ & 1,574 & 43 & 1,469 & 40.0 & 1,218 & 33.0 \\
\hline 5. & $\begin{array}{l}\text { West Aegean } \\
\text { region }\end{array}$ & 612.9 & 85 & 14 & 94 & 15.0 & 114 & 18.6 \\
\hline
\end{tabular}

Source: National strategy for management and development of the water sector in the Republic of Bulgaria decrease in water resources in the dams, which increases the percentage of water consumption about the quantities of water resources. 
There are still places in Bulgaria, including in the capital, where there are no sewerage or treatment facilities. This is a serious problem in the Bulgarian state, which is slowly being solved thanks to European funding. The data show that the percentage for Bulgaria is exceptionally low compared to other European countries (National strategy for management and development of the water sector in the Republic of Bulgaria, 2012)

Table 3. Percentage of population, related to domestic wastewater treatment.

\begin{tabular}{|l|r|r|r|r|r|r|r|r|r|}
\hline Country & 1999 & 2000 & 2001 & 2002 & 2003 & 2004 & 2005 & 2006 & 2007 \\
\hline Belgium & $:$ & 41 & 46 & 48 & 52 & 53 & 55 & 56 & 60 \\
\hline Bulgaria & 36 & $36^{\mathrm{E}}$ & $37^{\mathrm{E}}$ & $38^{\mathrm{E}}$ & $38^{\mathrm{E}}$ & $38^{\mathrm{E}}$ & $38^{\mathrm{E}}$ & $38^{\mathrm{E}}$ & 39 \\
\hline Czech Republic & $:$ & $:$ & $:$ & 70 & 71 & 71 & 73 & 73 & 75 \\
\hline Germany & $:$ & $:$ & 93 & $:$ & $:$ & 94 & $:$ & $:$ & 95 \\
\hline Estonia & 68 & 68 & 68 & 70 & 70 & 71 & 73 & 73 & 74 \\
\hline Greece & $:$ & $:$ & $:$ & $:$ & $:$ & $:$ & $:$ & $:$ & 85 \\
\hline Latvia & $:$ & $:$ & $:$ & 63 & 68 & 64 & 64 & 63 & 63 \\
\hline Lithuania & $:$ & $:$ & $:$ & 25 & 28 & $:$ & 57 & 59 & 61 \\
\hline Hungary & 25 & 30 & 29 & 36 & 39 & 41 & 52 & 55 & $:$ \\
\hline Malta & $13^{\mathrm{E}}$ & $13^{\mathrm{E}}$ & $13^{\mathrm{E}}$ & $13^{\mathrm{E}}$ & $13^{\mathrm{E}}$ & $13^{\mathrm{E}}$ & $13^{\mathrm{E}}$ & $13^{\mathrm{E}}$ & $13^{\mathrm{E}}$ \\
\hline Nederland & 98 & 98 & 98 & 99 & 99 & 99 & 99 & 99 & $:$ \\
\hline Poland & 48 & 50 & 52 & 54 & 56 & 57 & 58 & 61 & 62 \\
\hline Portugal & $:$ & $:$ & $:$ & 27 & 32 & $:$ & $:$ & 37 & 48 \\
\hline Romania & $:$ & $:$ & $:$ & $:$ & $:$ & $17^{\mathrm{E}}$ & $17^{\mathrm{E}}$ & $:$ & $:$ \\
\hline Slovenia & 14 & 14 & 16 & 19 & 20 & 29 & 31 & 48 & 47 \\
\hline
\end{tabular}

E - Estimated value

Source: (Eurostat, 2021)

\subsection{Investments in regional ecological infrastructure}

The improvement of the water infrastructure is especially important for the Bulgarian regions and municipalities. Analyzes show that the infrastructure is very morally and technically outdated, which requires a lot of maintenance. Due to the state of infrastructure, the losses of drinking water are significant. That is why investments in such infrastructure are an objective necessity. Theoretically, investments in water supply and sewerage facilities are characterized by long-term returns. This circumstance makes resolving this issue even more difficult. Usually, economic logic requires that in the long run, the projected consumption be large enough to be able to recoup the investment through the price of water and its consumption. On the other hand, consumption is related to the population of the regions. Demographic forecasts point to a decrease in the Bulgarian population and depopulation of large areas, which makes the improvement of water infrastructure difficult to implement.

According to some Bulgarian experts, investments in water infrastructure for renovation and rehabilitation, as well as for the construction of a new one, amount to BGN 12 billion (Gradat, 2010). This infrastructure in the capital city needs rehabilitation and a new one around BGN 2 billion. The annual city budget is BGN 1.7 billion. These data illustrate the other problem related to the financial provision of these large infrastructure projects in the regions.

Infrastructure investments are important for another reason. Due to climate change and the reduction of the estimated amounts of precipitation and drinking water in the reservoirs, it is necessary to use the water resource rationally. Otherwise, we risk reaching water regimes in many places in Bulgaria. This implies effective management of the water sector and prudent investment in environmental infrastructure. The main sources of financing are 
the taxes from the consumers, the funds of the $\mathrm{EU}$, the loans from the banks, the funds from the state budget, and the public-private partnership.

\subsection{Legislation and water sector management strategies}

The water sector in Bulgaria is characterized by a complex system of management and subordination. The Ministry of Environment and Water and the Ministry of Regional Development and Public Works have responsibilities and powers in this area. The quantities of water that are consumed, are managed and authorized by the Ministry of Environment and Water, while the infrastructure is owned by the water supply and sewerage companies, which are subordinated to the municipalities and the Ministry of Regional Development and Public Works.

Drink water and water resources are exclusive state property and state wealth. Because of this reason, the regulations on the use of water resources find material expression in the Constitution of the country, and specifically in Art. 18, paragraph 1 of the Constitution of the Republic of Bulgaria 9 (Constitution of The Republic of Bulgaria, 1991). In the basic normative act of the Bulgarian state, the underground resources and the land drink water are defined as an object of the exclusive state property. Based on the Constitution, specialized legislation has been adopted. This legislation includes the Water Act, the Environmental Protection Act (Water Act, 2000, Regulation' Act of water supply and sewerage companies' services, 2005, Environmental Protection Act, 2002). At the European level European commission has adopted The EU Water Framework Directive 2000/60 (EU Water Framework Directive 2000/60).

The strategies for the development of the water sector in Bulgaria and the operational management are subordinated to both the legislation and the need for financing of the sector. When we talk about the management of the sector, the question arises with the ownership of water and sewage companies. Here we can have different options, such as ownership to be state, municipalities, private sector on concession or public-private partnership.

In 2012, the National Assembly of the Republic of Bulgaria adopted a National Strategy for Management and Development of the Water Sector (National Strategy for Management and Development of the Water Sector, 2012). The strategic document aims to start solving the problems in the water sector. In this regard, plumbing associations were established. They had to unite all municipal companies to improve funding and governance. But the consolidation did not lead to highly positive results. Thus, small municipalities and settlements were neglected because of the central and regional cities.

\section{CONCLUSIONS}

In recent years, the Commission for State and Water Regulation in the Republic of Bulgaria has been gradually increasing the prices of water for domestic and economic needs. There is a chronic underfunding of the Bulgarian water sector. The state of the water sector in Bulgaria has not changed radically. Due to poor management, lack of funds, and postponement of capital investments, the condition of the water management infrastructure is drastically deteriorating. This leads to a significant increase in future costs. Much of the water supply network is morally and technically obsolete. Another major problem is the low percentage of the constructed sewerage network. These and many other problems require a change in the strategic and operational management of the water sector in Bulgaria. This is related to rational and efficient financing of the system, which will counteract the rapid increase in the price of water.

\section{WORKS CITED}

Eurostat. (2021, 02 08). Population connected to urban wastewater collecting and treatment systems, by treatment level. Retrieved from Eurostat: https://ec.europa.eu/eurostat/databrowser/view/ten00020/default/table?lang=en

Gradat. (2010, 03 31). 12 mlrd. leva sa nuzhni za investitsii vŭv vodniya sektor. Retrieved from Gradat: https://gradat.bg/infrastructure/2010/03/31/881247_12_mlrd_leva_sa_nujni_za_investicii_vuv _vodniia_sektor 
IBRD-IDA. (2017, Sep 20). Water resources management. Retrieved from The World Bank: https://www.worldbank.org/en/topic/waterresourcesmanagement

Kolcheva, K. (2019). Vodnite resursi v Bŭlgariya i tyakhnoto izpolzvane (Engl. Water resources in Bulgaria and their use). Proceedings of the Scientific Conference: Climate, atmosphere and water resources in the conditions of climate change (pp. 1-33). Sofia: Bulgarian Academy of Sciences.

Ministers Council. (2012). National Strategy for Management and Development of the Water Sector, Sofia.

Ministers Council. (2020). National report on the state and protection of the environment in 2020, Sofia.

State paper. (1991). Constitution of The Republic of Bulgaria, Sofia.

State paper. (2000). Water Act, Vol. 12, Sofia.

State paper. (2002). Environmental Protection Act, Vol. 91, Sofia.

State paper. (2005). Regulation' Act of water supply and sewerage companies' services, Vol. 18, Sofia.

Received for publication:

Revision received:

14.06.2021

25.06.2021

Accepted for publication:

\section{How to cite this article?}

Style - APA Sixth Edition:

Tsonkov, N. (2021, July 15). Water sector management and sustainable development of Bulgarian regions. (Z. Cekerevac, Ed.) MEST Journal, 9(2), 75-80. doi:10.12709/mest.09.09.02.11

Style - Chicago Sixteenth Edition:

Tsonkov, Nikolay. 2021. "Water sector management and sustainable development of Bulgarian regions." Edited by Zoran Cekerevac. MEST Journal (MESTE) 9 (2): 75-80. doi:10.12709/mest.09.09.02.11.

Style - GOST Name Sort:

Tsonkov Nikolay Water sector management and sustainable development of Bulgarian regions [Journal] // MEST Journal / ed. Cekerevac Zoran. - Belgrade - Toronto : MESTE, July 15, 2021. - 2 : Vol. 9. - pp. 75-80.

Style - Harvard Anglia:

Tsonkov, N., 2021. Water sector management and sustainable development of Bulgarian regions. MEST Journal, 15 July, 9(2), pp. 75-80.

Style - ISO 690 Numerical Reference:

Water sector management and sustainable development of Bulgarian regions. Tsonkov, Nikolay. [ed.] Zoran Cekerevac. 2, Belgrade - Toronto : MESTE, July 15, 2021, MEST Journal, Vol. 9, pp. 75-80. 